\title{
Epidemiological profile of cutaneous leishmaniasis in an endemic region in the State of Rio de Janeiro, Brazil
}

\author{
Perfil epidemiológico da leishmaniose cutânea em uma região \\ endêmica do Estado do Rio de Janeiro, Brasil \\ Maria Cristina Fortes Santos de Bustamante ${ }^{1}$; Maria Júlia Salim Pereira ${ }^{2 *}$; \\ Armando de Oliveira Schubach ${ }^{3}$; Adevair Henrique da Fonseca ${ }^{2}$ \\ 'Pós-graduação em Ciências Veterinárias, Instituto de Veterinária - IV, Universidade Federal Rural do Rio de Janeiro - UFRRJ \\ ${ }^{2}$ Departamento de Parasitologia Animal, Instituto de Veterinária - IV, Universidade Federal Rural do Rio de Janeiro - UFRRJ \\ ${ }^{3}$ Laboratório de Vigilância em Leishmanioses, Instituto de Pesquisas Evandro Chagas, Fundação Instituto Oswaldo Cruz - FIOCRUZ
}

Received April 3, 2008

Accepted June 8, 2009

\begin{abstract}
The objective of the present study was to investigate the dynamics and profile of American Cutaneous Leishmaniasis (ACL) in an old colonization area in the State of Rio de Janeiro. Health departments of municipalities in the Central-Southern region that had notified cases to the Ministry of Health's Notifiable Diseases Information System between 1997 and 2002 were contacted to obtain data. Out of the 119 cases recorded, 51 patients were visited for an interview and inspection of the environment. The cases of ACL exhibited a profile similar to that observed in other Brazilian cities, affecting individuals of both genders, all age groups and different occupational categories, especially students. Risk activities were reported by $56.9 \%$ of the interviewees and $84.3 \%$ had never left their homeland. Water courses, chicken coops, bamboo plantations and different fruit trees including banana plants and mango trees were frequently observed in the surrounding environment. Most of the interviewees had not noted any environmental changes prior to becoming sick. Domestic animals were present in all homes, but only dogs presented lesions suggestive of the disease. These were on different occasions that rarely preceded or coincided with the human cases. The possible existence of distinct transmission cycles, i.e. one for canines and another for humans, was discussed.
\end{abstract}

Keywords: American Cutaneous Leishmaniasis, Leishmania (Viannia) braziliensis, zoonotic diseases, epidemiology.

\section{Resumo}

Este estudo teve como objetivo conhecer a dinâmica e o perfil da Leishmaniose Tegumentar Americana (LTA) em uma área de colonização antiga do Estado do Rio de Janeiro. As secretarias de saúde dos municípios da Região Centro-Sul que notificaram casos ao Sistema de Informação de Agravos de Notificação do Ministério da Saúde entre os anos de 1997 e 2002 foram contactadas para obtençáo dos dados. Do total de 119 casos registrados, 51 pacientes foram visitados para realização de entrevista e observaçáo do ambiente. A LTA exibiu perfil semelhante ao de outras cidades brasileiras, acometendo indivíduos de ambos os sexos, de todas as faixas etárias e diversas categorias ocupacionais, principalmente estudantes. A realizaçáo de atividades de risco foi relatada por $56,9 \%$ dos entrevistados e $84,3 \%$ não se deslocaram do município de residência. No ambiente circundante havia, frequentemente, cursos d'água, galinheiros, bambuzais e diversas frutíferas, entre elas: bananeiras e mangueiras. A maioria dos entrevistados náo observou mudanças ambientais anteriormente ao adoecimento. Animais domésticos estiveram presentes em todos os domicílios, mas apenas cães evidenciaram lesôes sugestivas da doença em ocasiôes diversas, raramente antecedendo ou coincidindo com casos humanos. A possibilidade de existirem ciclos de transmissão distintos, um canino e outro, humano, foi discutida.

Palavras-chave: Leishmaniose Tegumentar Americana, Leishmania (Viannia) braziliensis, zoonoses, epidemiologia.

*Corresponding author: Maria Julia Salim Pereira

Departamento de Parasitologia Animal, Instituto de Veterinária - IV,

Universidade Federal Rural do Rio de Janeiro - UFRRJ, BR 465, km 7 ,

CEP 2389-000 Seropédica - RJ, Brazil; e-mail: m.salim@ufrri.br

Supported by: Fundação de Amparo à Pesquisa do Rio de Janeiro

(E-26/171.361/ 2002-APQ1) and CAPES 


\section{Introduction}

American Cutaneous Leishmaniasis (ACL) was present on the American continent before the European colonization (ENCISO et al., 2003). It is a chronic deforming disease whose main epidemiological characteristic at the beginning of the $20^{\text {th }}$ century was that it affected defined risk groups, such as adult men exposed to vectors during activities such as hunting, fishing, extractive activities and agriculture (ACHA; SZIFRES, 1986). The first clinical observations of ACL in Brazil date back to the $19^{\text {th }}$ century during the railroads construction. However, the disease went on losing its importance for public health as humans started to occupy areas that had already been devastated (PESSÔA; MARTINS, 1988), and through intense anti-malaria campaigns (NERY-GUIMARÃES, 1955). In view of the declining numbers of human cases recorded, Sampaio (1951) suggested that leishmaniasis would disappear within a few years as a consequence of deforestation, since the existence of the disease had been solely associated with the presence of wild animals. Until the end of the 1960s, ACL was believed to only occur close to woods, rainforest remnants or newly deforested areas, affecting rural workers and settlers who migrated to recently colonized areas. The possibility that the disease would affect individuals outside these areas was considered to be zero (FORATTINI, 1973). At the end of the 1970s, ACL was described among individuals living in an old colonization area (MAYRINK et al., 1979). Today, domestic cycle has been observed, with increased transmission inside and in areas surrounding homes (DESJEUX, 2001).

The role of animals in the transmission cycles of ACL has been the subject of several studies (BRANDÃO-FILHO et al., 2003; REITHINGER et al. 2003; SCHUBACH et al., 2004). In Brazil, since the beginning of the last century, parasites of the genus Leishmania have been detected in domestic and wild animals (PESSÔA; MARTINS, 1988). Forattini (1960) suggested that a process of speciation and adaptation of the parasite to humans and to domestic animals might exist, in which the protozoan would search for new hosts in a modified environment. Thus, humans and dogs might become reservoirs for the protozoan and would represent distinct and independent transmission cycles for ACL (extra-forestal cycle).

Since autochthonous cases of ACL have been observed in the central-southern region of the State of Rio de Janeiro, an old colonization area, the objective of the present study was to better understand the dynamics and profile of this disease in the region, identifying distinct characteristics in the transmission cycle of the parasite.

\section{Materials and Methods}

The study area measured $3,038 \mathrm{~km}^{2}$ and comprised the municipalities of Engenheiro Paulo de Frontin, Mendes, Vassouras, Miguel Pereira, Paty do Alferes, Paraíba do Sul, Três Rios, Areal, Sapucaia and Comendador Levy Gasparian, which administratively correspond to the central-southern region of the State of Rio de Janeiro, Brazil (FUNDAÇÃO CENTRO DE INFORMAÇÓES
E DADOS DO RIO DE JANEIRO, 2003). The total population of the region was 254,103 inhabitants.

On the basis of the 119 cases recorded in the Notifiable Diseases Information System between 1997 and 2002 (SECRETARIA DE SAÚDE DO ESTADO DO RIO DE JANEIRO, 2003), the health departments of the notifying municipalities were contacted in 2003, which was when the present study was conduced. On this occasion, unfounded notifications were excluded and others that had yet not entered the system were included. Patients who lived in very remote or forested areas at the time when they became sick, along with those who had the habit of fishing, hunting or camping in rain forests, were excluded from the study.

Each patient was visited at his/her home to apply a structured interview in order to collect personal data and information on their habits, the characteristics of the process of becoming ill and their interpretation of the disease. An environmental survey was also performed, to record any presence of animals and their shelters, the type and density of the vegetation and the distance between these items and the dwelling. The surrounding environment and any lesions that were found were recorded and also photographed. On this occasion, the patients received detailed information about the study and their rights, and those who agreed to participate in the study signed a free and informed consent form. If the patient was illiterate or unable to read, the content was read by a relative or neighbor who jointly signed the form.

In addition, data regarding suggestive lesions in animals were obtained during the interviews with the patients and through personal communication with veterinarians working in the region, as well as from healthcare workers of the public municipal networks. Information regarding the presence of Lutzomyia sp. was obtained from the literature.

The data obtained were computed and stored in a database set up using the Epi Info 2002 software (CENTERS FOR DISEASE CONTROL, 2003). These data were subjected to exploratory analysis (PINHEIRO; TORRES, 2002).

\section{Results}

During the study period, the annual incidence of ACL in the region ranged from 0.04 to 2.44 cases per 10,000 inhabitants and, except for Comendador Levy Gasparian and Paraíba do Sul, all municipalities reported cases (Table 1).

Seventy-four subjects fulfilled the criteria for inclusion in the study, but only 51 , living in 41 dwellings, were interviewed. The remaining 23 subjects could not be located for various reasons. Of the 51 patients interviewed, $58.8 \%$ were men and $41.2 \%$ were women. The 15 to 49 -year age group was the one most affected. The patients' ages ranged from two to 72 years (mean: 27.35, median: 25 and mode: 13 years). The incidence of ACL according to age group is shown in Table 2.

With regard to educational level, subjects with incomplete elementary school (29\%), illiterates (11.8\%) and preschool children $(7.8 \%)$ predominated. Regarding occupational activity, the largest number of cases was observed among students ( $\mathrm{n}=13,25.5 \%)$, followed by farmers $(n=11,21.6 \%)$. At least one of the risk activities such as plant extraction, firewood collection and farming 
Table 1. Annual incidence of American Cutaneous Leishmaniasis in municipalities in the Central-Southern region of the State of Rio de Janeiro, Brazil, 1997-2002.

\begin{tabular}{|c|c|c|c|c|c|c|}
\hline \multirow{2}{*}{ Municipality } & \multicolumn{6}{|c|}{ Incidence*/year } \\
\hline & 1997 & 1998 & 1999 & 2000 & 2001 & 2002 \\
\hline Areal & - & - & 1.06 & - & - & - \\
\hline Engenheiro Paulo de Frontin & - & - & - & 0.82 & - & 0.82 \\
\hline Mendes & - & 0.57 & 1.70 & - & - & - \\
\hline Miguel Pereira & - & - & 3.88 & - & - & 1.21 \\
\hline Paty do Alferes & - & 0.88 & - & - & 0.38 & 0.39 \\
\hline Sapucaia & - & - & 18.09 & 4.08 & - & - \\
\hline Três Rios & 0.15 & - & 0.60 & - & 0.14 & - \\
\hline Vassouras & - & 7.51 & 4.76 & 3.18 & 0.63 & 1.25 \\
\hline Total & 0.04 & 0.98 & 2.44 & 0.71 & 0.16 & 0.34 \\
\hline
\end{tabular}

${ }^{*}$ Per 10,000 inhabitants. (Source: Secretaria de Saúde do Estado do Rio de Janeiro, 2003).

and cattle rearing was performed by $29(56.9 \%)$ of the patients, whereas $22(43.1 \%)$ were not engaged in any of these activities.

The length of time living in the dwelling where the patient became sick is shown in Table 3. With regard to the area of residence, 16 patients $(31.4 \%)$ were living in an urban area at the time when they became sick, seven $(13.7 \%)$ in an urban fringe area and 28 (54.9\%) in rural settlements.

Moving around within the municipality of residence (mainly for parties, religious practices and other night or evening events) was reported by $19(37.3 \%)$ patients, and trips outside the municipality during the months preceding the occurrence of symptoms were reported by eight $(15.7 \%)$. The habit of remaining outside the house, in the evening, was reported by 24 (47.1\%) of the patients interviewed.

The interval between the occurrence of the lesion and the diagnosis of the disease ranged from days $(n=16,31.4 \%)$ to months ( $n=35,68.6 \%)$. All of the patients presented healed skin lesions, but four $(7.8 \%)$ manifested paresthesia at the site of the lesion. Forty-one $(80.4 \%)$ of the 51 patients attended control visits after the skin lesions had healed.

Only $21(41.2 \%)$ of the patients interviewed left a light on inside $(n=16,31.4 \%)$ or outside the dwelling $(n=5,9.8 \%)$ during the night. The remaining 30 patients (58.5\%) slept with all lights turned off.

Domestic animals were present around all dwellings. Dogs (88.2\%), domestic fowl such as chickens and ducks (68.6\%), horses $(64.7 \%)$ and small birds $(52.9 \%)$ were the most frequent, followed by cats and cattle (51\% each) and pigs (49\%). Wild birds, goats and sheep were only found in a few dwellings, and no wild mammals were observed. Among all of the domestic animals observed, only dogs showed clinical signs of cutaneous leishmaniasis. Most patients (88.1\%) had not seen any animal with lesions suggestive of ACL before or after the onset of their own illness. Only four patients (9.5\%) had observed suggestive lesions on their own dogs, several months before becoming sick themselves, and four other patients had seen them months or years later, on dogs in the neighborhood (Table 4).
Table 2. Proportional distribution of cases of American Cutaneous Leishmaniasis according to age groups among the 51 patients interviewed in the municipalities in the Central-Southern region of the State of Rio de Janeiro, Brazil, 1997-2002.

\begin{tabular}{ccc}
\hline Age group (years) & Cases & Proportional distribution \\
\hline $1-5$ & 3 & 5.9 \\
$6-14$ & 13 & 25.5 \\
$15-49$ & 30 & 58.8 \\
$50-65$ & 0 & 0 \\
$>65$ & 5 & 9.8 \\
Total & 51 & 100 \\
\hline
\end{tabular}

Table 3. Absolute and relative frequencies of numbers of years of living in the dwelling where the 51 interviewed patients contracted American Ccutaneous Leishmaniasis in the municipalities in the Central-Southern region of the State of Rio de Janeiro, Brazil, 2003.

\begin{tabular}{ccccccc}
\hline & \multicolumn{6}{c}{ Length of time living in dwelling (years) } \\
\cline { 2 - 7 } Frequency & $<\mathbf{1}$ & $\mathbf{1 - 2}$ & $\mathbf{2 - 5}$ & $\mathbf{5 - 1 0}$ & $\mathbf{+ 1 0}$ & $\begin{array}{c}\text { Did not } \\
\text { remember }\end{array}$ \\
\hline Absolute & 5 & 4 & 5 & 10 & 26 & 1 \\
Relative (\%) & 9.8 & 7.8 & 9.8 & 19.6 & 51 & 2.0 \\
\hline
\end{tabular}

The perception of the presence of biting mosquitoes was greater during the afternoon and evening periods $(\mathrm{n}=41,80.4 \%)$ but no difference was noted between inside and around the dwelling $(\mathrm{n}=23,45.1 \%)$. Fumigation was performed by several of the subjects as a measure to repel insects, including the burning of old clothes or leaves as an alternative to chemical control, which was unachievable by most patients. More than half of the patients did not use any type of protection against insects.

The construction methods used in the 41 dwellings visited were stucco in $12.2 \%$ and bricks in $87.8 \%$. Mud or amianthus tiles were present in $92.7 \%$ of the dwellings. Since no ceiling cover or 
Table 4. Human cases $(\mathrm{H})$ of American cutaneous leishmaniasis and reports of occurrences of the disease in canines $(\mathrm{C})$ in the Central-Southern region of the State of Rio de Janeiro between 1997 and 2002.

\begin{tabular}{|c|c|c|c|c|c|c|c|c|c|c|c|c|c|}
\hline \multirow[t]{3}{*}{ Municipality } & \multicolumn{12}{|c|}{ Number of human cases and reports of canine cases / year } & \multirow[t]{3}{*}{ Total } \\
\hline & \multicolumn{2}{|c|}{1997} & \multicolumn{2}{|c|}{1998} & \multicolumn{2}{|c|}{1999} & \multicolumn{2}{|c|}{2000} & \multicolumn{2}{|c|}{2001} & \multicolumn{2}{|c|}{2002} & \\
\hline & $\mathbf{H}$ & $\mathbf{C}$ & $\mathbf{H}$ & C & $\mathbf{H}$ & C & $\mathbf{H}$ & C & $\mathbf{H}$ & C & $\mathbf{H}$ & C & \\
\hline Areal & - & - & - & - & 1 & - & - & - & - & - & - & - & 1 \\
\hline Comendador Levy Gasparian & - & - & - & - & - & - & - & - & - & - & - & - & - \\
\hline Engenheiro Paulo de Frontin & - & - & - & - & - & - & 1 & - & - & - & 1 & - & 2 \\
\hline Mendes & - & - & 1 & - & 3 & - & - & Yes & - & Yes & - & - & 4 \\
\hline Miguel Pereira & - & - & - & - & 8 & - & - & - & - & - & 3 & - & 11 \\
\hline Paty do Alferes & - & - & 2 & - & - & - & - & - & 1 & - & 1 & - & 4 \\
\hline Paraíba do Sul & - & - & - & - & - & - & - & - & - & - & - & - & - \\
\hline Sapucaia & - & - & - & - & 32 & Yes & 7 & - & - & - & - & - & 39 \\
\hline Três Rios & 1 & - & - & - & 4 & - & - & - & 1 & - & - & Yes & 6 \\
\hline Vassouras & - & - & 22 & Yes & 14 & Yes & 10 & Yes & 2 & Yes & 4 & - & 52 \\
\hline Total & 1 & - & 25 & - & 62 & - & 18 & - & 4 & - & 9 & - & 119 \\
\hline
\end{tabular}

slabstone was present in $31(75.6 \%)$ of the dwellings, the rooms communicated via the roof space. The windows were simple in $35(85.4 \%)$ of the dwellings. Window slits at one or more sites of the houses were observed in $34(82.9 \%)$ of the dwellings.

Most houses $(n=26,63.4 \%)$ were not connected to other dwellings or animal rearing sheds, but vegetation close to or leaning against the outside walls was observed in 28 (68.3\%). In $24(58.5 \%)$ of the dwellings, manure was used in vegetable or flower gardens.

Thirty-five $(85.4 \%)$ of the 41 dwellings were located near to other houses. The nearness of the other six dwellings was unknown.

Fruit trees of a variety of types were present around and in the neighborhood of 41 dwellings (100\%), including banana plants in $100 \%$ and mango trees in $85.4 \%$. Brushwood $(n=40$, $97.6 \%)$, water streams and springs $(\mathrm{n}=39,95.1 \%)$, various types of trees $(\mathrm{n}=38,92.7 \%)$ and bamboo shrubs $(\mathrm{n}=30,73.2 \%)$ were also observed.

Around seven dwellings, cutting down mango trees and other trees and clearing brushwood from the ground seemed to have resulted in the displacement of vectors toward human habitations. These factors were associated by the patients with occurrences of "mosquitoes", although this condition was not reported by the people living in the other dwellings investigated.

\section{Discussion}

The profile of human cases of ACL studied in the central-southern region of the State of Rio de Janeiro was similar to that reported in similar studies conducted in certain Brazilian cities. However, some of the observations were found to be interesting and polemical. More than half of the subjects affected had been living at the place where the infection occurred for more than 10 years, thus indicating that they were not infected by recent arrival in an area at risk. This suggests that changes may have occurred in the surrounding environment, such as human and animal migration and changes in the vegetation, sandfly fauna or epidemiological pattern of the disease, as reported by Gomes et al. (1990) and Desjeux (2001).

Most of the patients studied belonged to the more underprivileged socioeconomic strata, in which individuals do not have the ability to combat the vectors. This was also reported by other investigators (SANTOS et al., 2000; GONTIJO et al., 2002). However, the presence of ACL in several members of the same family, simply through sharing the same habitat and therefore being exposed to similar risks (SANTOS et al., 2000), may not explain the repeated observation of this condition, in various municipalities. Other factors probably contributed towards this finding. In all the dwellings visited in which family case aggregation was observed, the degree of kinship between the affected individuals was consanguineous (for example, a woman and her five children, but not her husband; and a woman, her son and her granddaughter, but not her daughter-in-law), thus suggesting genetic predisposition towards the development of the disease. These observations agree with studies conducted on mice that showed that susceptibility to Leishmania donovani is apparently mediated by genes (MOLYNEUX; ASHFORD, 1983). In addition, familial aggregation of mucosal leishmaniasis and cutaneous leishmaniasis was demonstrated by Castellucci et al. (2005), and the risk of falling ill was found to be 4.5 times higher in a dwelling with sick individuals than in dwellings where nobody presented the disease (FOLLADOR et al., 1999). Although in the present study the aggregations may have been due to a common source of exposure or to possible anthroponotic transmission (ROJAS, 2001), they may also have been due to genetic susceptibility.

The persistence and viability of Leishmania (Viannia) braziliensis in ancient scars, many years after patients have achieved a clinical cure, suggests that humans may carry the protozoan throughout life (SCHUBACH et al., 1998). If humans act as a reservoir, intense human migration from rural endemic areas to the periphery of urban areas might be contributing towards the urbanization of the disease (MARZOCHI; MARZOCHI, 1994; AGUDELO et al., 2002). In the city of Rio de Janeiro, it was observed that the urbanization process produced the conditions to strengthen an 
endemic pattern of well-defined outbreaks in areas where human mobility and work processes enabled enlargement of contact between susceptible individuals and vectors (KAWA; SABROZA, 2002). This situation was also observed in the municipality of Vassouras, which was characterized by extensive internal migration, thereby impairing and sometimes preventing the localization of many patients due to constant changes of address, because of the search for work or for less expensive rents.

In contrast to the reports of Passos et al. (1996), Barbosa Santos et al. (1998) and Barbosa et al. (1999), symptomatic cases of canine cutaneous leishmaniasis did not necessarily accompany human disease in the present study. Santos et al. (2005) observed a high prevalence of canine infection associated with low endemicity of the human disease in an urban area of the municipality of Paracambi, State of Rio de Janeiro, a finding that cast doubt on the importance of dogs in the transmission chain.

The cases from the municipality of Sapucaia reflect the conflicting views about the importance of human and animal infections in the transmission cycle of ACL. The steep topography of the municipality and its extent impair the dispersal of vectors and animals, thus maintaining geographically isolated niches. Hence, the reports from people living in that municipality indicated that canine and human cases did not overlap in time or space, i.e. human cases occurred independently of evidence of lesions in animals and vice-versa. Thirty-two human cases were notified in 1999, following three years without any notifications. According to the reports from people living there, this coincided with the arrival of farmers from an endemic municipality in the neighboring State of Minas Gerais. Both the human and the canine cases that occurred in 1999 were accompanied and photographed by the Municipal Health Department and were confirmed as ACL by laboratory diagnostics.

In the municipality of Mendes, five cases of canine ACL were observed in the Independência and Cinco Lagos neighborhoods in 1999 and 2000, respectively. In four of the five symptomatic dogs, the diagnosis was confirmed at the Fundaçáo Oswaldo Cruz, including three cases by means of serological tests and one by imprint and serological tests. No human cases were reported in any of the neighborhoods at that time, even though Independência was a densely populated low-income housing development. Only at the end of 2002 were suggestive lesions observed in two individuals from Cinco Lagos: these were only confirmed and notified in 2003, and therefore were excluded from this study. In an attempt to investigate the latest animal cases, every house in Cinco Lagos was visited by Community Health Agents, to carry out an active search. No other dogs with lesions were identified after the initial episode, up to 2003, when this study was concluded.

The municipality of Vassouras is a relatively recent site for transmission of ACL. A spatio-temporal overlap of canine and human cases was only observed in this municipality. It is possible that the large number of horses, which are an abundant source of blood meals for phlebotomines (AFONSO et al. 2005), in the municipality may facilitate the feeding and multiplication of sandflies, thus causing increased transmission levels. Despite this, no horses presenting lesions or a history of the disease were found. The index case from this municipality occurred in 1995, along a federal highway, near a tire repair shop and a restaurant, after extensive tree felling.

The role of dogs and other domestic animals in the extra-forestal cycle of ACL transmission is highly controversial. Some authors have only isolated parasites from skin lesions (MADEIRA et al., 2005, 2006; CASTRO et al., 2007). Moreover, Castro et al. (2007) suggested that dogs are not good reservoirs for $L .(V$.$) braziliensis$ and Massunari et al. (2009) suggested that dogs have a secondary role in the transmission cycle of this parasite. As seen with human infection, the results from diagnostic tests on animals are discrepant, thus raising doubts regarding their validity (UCHÔA et al., 2001). There is still no concrete evidence that domestic animals act as reservoirs, since they are not always present inside or around the infected person's dwelling. However, as in humans themselves, animals may play a fundamental role in maintaining the disease within the human environment (SILVEIRA et al., 1999). Therefore, the transmission cycle of ACL needs to be better investigated and understood (GOMES et al. 1990), since it is likely to be affected by environmental disturbances caused by human interference, which would impair the stability of the relationships between vector populations and enable contact between these vectors and susceptible hosts (MELLO, 1991). In this respect, the results from the present study support the need for continuous investigation of risk factors for leishmaniasis, as emphasized by Tolezano (1994).

The diversity of situations observed in the cases studied in this region, which varied according to the municipality of origin, indicates that animals may or may not be part of the transmission cycle under particular circumstances. This suggests the possibility that anthroponotic transmission and different cycle relationships may occur according to the vectors present.

Considering the distribution (FERREIRA et al., 2001) and sandfly host preferences, it is important investigate the impact that the presence and abundance of each vector have on the epidemiological cycles, involving canine and human outbreaks. On the other hand, the possibility that species of other taxa may be involved in transmission to dogs cannot be ignored, since experimental evidence has demonstrated the infection of Rhipicephalus sanguineus by Leishmania chagasi (COUTINHO et al., 2005).

The surrounding environment also seems to strongly influence occurrences of leishmaniasis as a result of the interaction of the community with the forest (NERY-GUIMARÃES, 1955; FOLLADOR et al., 1999; UCHÔA et al., 2001) and as a result of human changes that favor the establishment and growth of anthropophilic vectors (TEODORO et al., 1999). After significant changes in the surrounding environment or insecticide spraying, large numbers of anthropophilic phlebotomine species (such as Lutzomyia intermedia and L. migonei) are frequently observed inside and around dwellings at higher percentages than observed among the previously predominant wild species (DOMINGOS et al., 1998). This demonstrates that these factors exert a large influence on the dominance relationship, population size and biodiversity of the phlebotomine sandfly fauna (TEODORO et al., 1999). Areas that have undergone intense changes as a result of human action and that are densely populated become endemic at different times, and this cannot always be attributed to the occurrence of 
deforestation prior to the introduction of the disease into the community (MAYRINK et al., 1979).

Since anthropophilic species are the ones best adapted to human conditions, it is of interest to note that there were no autochthonous cases notified from Engenheiro Paulo de Frontin. This municipality has an extensive plant cover of original and recovered rain forest that possibly maintains anthropophilic phlebotomine populations at low densities controlled by competition with other forest species. However, the inverse situation was observed in Paraíba do Sul and Comendador Levy Gasparian, where no cases were notified. These municipalities exhibit intensive forest degradation with no visible areas of primary rain forest, apparently providing conditions that are favorable for multiplication of phlebotomine sandflies such as L. intermedia. However, the excessively dry soil and exposure to solar radiation probably do not provide good conditions for their reproduction. In Três Rios, as reported by one of the patients interviewed, old transmission areas have shown a decline in moisture levels accompanied by prolonged dry seasons and death of the exuberant vegetation. This environmental change might be harmful to sandflies, which require damp places for oviposition, with moisture levels not allowing the multiplication of these insects at levels that would pose a risk to human health. In Paty do Alferes, although the degraded environment was considered to be favorable for the establishment of $L$. intermedia, only a few sporadic cases were observed, probably because of the intensive use of pesticides on farms and the small area of residual forest. Municipalities in which no cases of ACL are observed are not necessarily unaffected areas, since the estimated undernotification of this disease is high, especially if ulcers involute spontaneously. Moreover, the subclinical infection rates are unknown.

Transmission in areas surrounding dwellings has been reported from old colonization areas (MAYRINK et al., 1979; GOMES et al., 1992) and such areas have been shown to be associated with the risk of infection (PEDROSA, 2007). However, to attribute a risk to each component investigated, it would be necessary to determine its presence or absence in environments with and without ACL transmission. Studies evaluating infection rates in healthy animals and humans, as well as the vector density in the two environments, will be fundamental for broadening knowledge on the process of endemization of cutaneous leishmaniasis.

Better understanding of the adaptation dynamics of sandflies needs to be achieved rapidly, before these insects once and for all become adapted to the environment and to human hosts, in the way that has already been observed for Aedes aegypti. The existence of an incriminated vector seems to be the only condition necessary for the maintenance and propagation of leishmaniasis. Studies on environmental changes that favor the proliferation of anthropophilic vectors should be conducted in areas with different plant covers and variable climatic conditions, in order to anticipate the multiplication of the vector under certain situations. The fact that three patients reported occurrences of mosquito bites associated with the appearance of lesions in broad daylight (two outside the dwelling and one while climbing a mango tree) should be taken as a warning. Since sandflies usually breed at night (GOMES et al., 1983), this finding might indicate a change in vector behavior that requires close monitoring and more detailed investigation.

\section{References}

ACHA, P.; SZIFRES, B. Leishmaniasis Cutânea. In: ACHA, P.; SZIFRES, $B$. Zoonosis y enfermedades transmisibles comunes al hombre y a los animales. 2 ed. Washington: Organización Panamericana de la Salud, 1986. p. 615-626.

AFONSO, M. M. S. et al. Studies on the feeding habits of Lutzomyia (N.) intermedia (Diptera, Psychodidae), vector of cutaneous leishmaniasis in Brazil. Cadernos de Saúde Pública, v. 21, n. 6, p. 1816-1820, 2005.

AGUDELO, L. A. et al. Presence of american leishmaniasis vectors surrounding the City of Medelín, Colombia. Memórias do Instituto Oswaldo Cruz, v. 97, n. 5, p. 641-642, 2002.

BARBOSA, G. M. S. et al. Aspectos epidemiológicos da leishmaniose tegumentar americana em cães, no Município de Paraty, Estado do Rio de Janeiro, Brasil. Cadernos de Saúde Pública, v. 15, n. 3, p. 641-646, 1999.

BARBOSA-SANTOS, E. G. G. et al. Epidemiological survey on canine population with the use of immunoleish skin test in endemic áreas of human american cutaneous leishmaniasis in the state of Rio de Janeiro, Brazil. Revista do Instituto de Medicina Tropical de Sáo Paulo, v. 40, n. 1, p. 41-47, 1998.

BRANDÁO-FILHO, S. P. et al. Wild and synanthropic hosts of Leishamnia (Viannia) braziliensis in the endemic cutaneous leishmaniasis locality of Amaraji, Pernambuco State, Brazil. Transactions of the Royal Society of Tropical Medicine and Hygiene, v. 97, n. 3, p. 291-296, 2003.

CASTELLUCCI, L. A. et al. Familial aggregation of mucosal leishmaniasis in Northeast Brazil. American Journal of Tropical Medicine and Hygiene, v. 73, n. 1, p. 69-73, 2005.

CASTRO, E. A. et al. Leishmania (Viannia) braziliensis: epidemiology of canine cutaneous leishmaniais in the state of Parana (Brazil). Experimental Parasitology, v. 117, n. 1, p. 13-21, 2007.

CENTERS FOR DISEASE CONTROL. EPINFO 2002. Disponível em:< http://www.cdc.gov/epiinfo>. Acesso em: 13 Outubro 2003.

COUTINHO, M. T. Z. et al. Participation of Rhipicephalus sanguineus (Acari: Ixodidade) in the epidemiology of canine visceral leishmaniasis. Veterinary Parasitology, v. 128, n. 1-2, p.149-155, 2005.

DESJEUX, P. The increase in risk factors for leishmaniasis worldwide. Transactions of the Royal Society of Tropical Medicine and Hygiene, v. 95 , n. 3, p. 239-243, 2001

DOMINGOS, M. F. et al. Leishmaniose tegumentar americana: flebotomíneos de área de transmissão, no município de Pedro de Toledo, regiāo sul do Estado de São Paulo, Brasil. Revista da Sociedade Brasileira de Medicina Tropical, v. 31, n. 5, p. 425-432, 1998.

ENCISO, A. J. A. et al. Sobre a origem e dispersão das leishmanioses cutânea e mucosa com base em fontes históricas pré e pós-colombianas. Historia Ciências Saúde Manguinhos, v. 10, n. 3, p. 853-882, 2003.

FERREIRA, A. L. et al. Distribution of sand falies (Díptera: Psychodidae) at different altitudes in na endemicaregion of american cutaneous leishmaniasis in the state of Espírito Santo, Brazil. Memórias do Instituto Oswaldo Cruz, v. 96, n. 8, p. 1061-1067, 2001.

FOLLADOR, I. et al. Surto de leishmaniose tegumentar americana em Canoa, Santo Amaro, Bahia, Brasil. Revista da Sociedade Brasileira de Medicina Tropical, v. 32, n. 5, p. 497-503, 1999. 
FORATTINI, O. P. Sobre os reservatórios naturais da leishmaniose tegumentar americana. Revista do Instituto de Medicina Tropical de São Paulo, v. 2, n. 4, p. 195-203, 1960.

FORATTINI, O. P. Entomologia Médica. São Paulo: Edgard Blucher, $1973.658 \mathrm{p}$.

FUNDAÇÃO CENTRO DE INFORMAÇÓES E DADOS DO RIO DE JANEIRO, 2003. Disponível em:<http://www.cide.rj.gov.br>. Acesso em: 15 Junho 2003.

GOMES, A. C. et al. Aspectos ecológicos da leishmaniose tegumentar americana.Avaliação da atividade enzoótica de Leishamnia (Viannia) braziliensis, em ambiente florestal e peridomiciliar, regiáo do Vale da Ribeira, Estado de São Paulo, Brasil. Revista do Instituto de Medicina Tropical de Sáo Paulo, v. 32, n. 2, p. 105-15, 1990.

GOMES, A. C. et al. Aspectos ecológicos da leishmaniose tegumentar americana 3. Observaçóes naturais sobre o ritmo diário da atividade de Psychodopygus intermedius em ambiente florestal e extraflorestal. Revista de Saúde Pública, v. 17, n. 1, p. 23-30, 1983.

GOMES, A. C. et al. Aspectos ecológicos da leishmaniose tegumentar americana. Prevalência/incidência da infecção humana nos municípios de Pedro Toledo e Miractu, São Paulo, Brasil. Revista do Instituto de Medicina Tropical de Sáo Paulo, v. 34, n. 2, p. 149-158, 1992.

GONTIJO, C. M. F. et al. Epidemiological studies of an outbreak of cutaneous leishmaniasis in the Rio Jequitinhonha Valley, Minas Gerais, Brazil. Acta Tropica, v. 81, n. 2, p. 143-150, 2002.

KAWA, H.; SABROZA, P. C. Espacialização da leishmaniose tegumentar na cidade do Rio de Janeiro. Cadernos de Saúde Pública, v. 18, n. 3, p. $853-865,2002$.

MADEIRA, M. de F. et al. Leishmania (Viannia) braziliensis preferentially restricted to the cutaneous lesions of naturally infected dogs? Parasitology Research, v. 97, n. 1, p. 73-76, 2005.

MADEIRA, M. de F. et al. Post mortem parasitological evaluation of dogs seroreactive for Leishmania from Rio de Janeiro, Brazil. Veterinary Parasitology, v. 138, n. 3-4, p. 366-370, 2006.

MARZOCHI, M. C. A.; MARZOCHI, K. B. F. Tegumentary and visceral leishmaniasis in Brazil Emerging antropozoonosis and possibilities for their control. Cadernos de Saúde Pública, v. 10, supl. 2, p. 359-375, 1994.

MASSUNARI, G. K. et al. A serological and molecular investigation of American cutaneous leishmaniasis in dogs, three years after an outbreak in the Northwest of Paraná State, Brazil. Cadernos de Saúde Pública, v. 25 , n. 1 , p. $97-104,2009$.

MAYRINK, W. et al. Epidemiology of dermal leishmaniasis in the Rio Doce Valley, State of Minas Gerais, Brazil. Annals of Tropical Medicine and Parasitology, v. 73, p. 123-37, 1979.

MELLO, D. A. Parasitic diseases in Brazil and the role of wild mammals: An analysis based on leishmaniasis, Chaga's disease and schistossomiasis mansoni. Ciência e Cultura, v. 43, p. 274-278, 1991.

MOLYNEUX, D. H.; ASHFORD, R. W. The Biology of Trypanosoma and Leishmania Parasites of Man and Domestic Animals. New York: International Publications Service, 1983.

NERY-GUMARÁES, F. Estudo de um foco de Leishmaniose muco-cutânea na Baixada Fluminense (Estado do Rio de Janeiro). Memórias do Instituto Oswaldo Cruz, v. 53, n. 1, p. 1-11, 1955.

PASSOS, V. M. A. et al. Inquérito canino em foco recente de leishmaniose tegumentar no município de Sabará, região metropolitana de Belo
Horizonte. Revista da Sociedade Brasileira de Medicina Tropical, v. 29, n. 4, p. 323-329, 1996.

PEDROSA, F. de A. Fatores de risco para leishmaniose tegumentar (LTA) no estado de Alagoas, Brasil. Recife, 2007.102 f. Tese (Doutorado em Medicina Tropical) - Universidade Federal de Pernambuco.

PESSÔA, S. B.; MARTINS, A. V. Leishmanioses tegumentares. In: PESSOA, S. B.; MARTINS, A. V. Parasitologia Médica. Rio de Janeiro: Guanabara-Koogan, 1988. p. 78-87.

PINHEIRO, R. S.: TORRES, T. Z. G. de. Análise exploratória de dados. In: MEDRONHO, R. A. et al. Epidemiologia. São Paulo: Atheneu, 2002. cap. 16 , p. 227-244.

REITHINGER, R. et al. Domestic dog ownership: a risk factor for human infection with Leishmania (Viannia) species. Transactions of the Royal Society of Tropical Medicine and Hygiene. v. 97, n. 2, p. 141-145, 2003.

ROJAS, C. A. An ecosystem approach to human health and the prevention of cutaneous leishmaniasis in Tumaco, Colômbia. Cadernos de Saúde Pública, v. 17, supl., p. 193-200, 2001.

SAMPAIO, L. F. O aparecimento, a expansão e o fim da leishmaniose no Estado de São Paulo. Revista Brasileira de Medicina, v. 8, n. 10, p. 717-721, 1951.

SANTOS, G. P. L. et al. Prevalência da infecção canina em áreas endêmicas de leishmaniose tegumentar americana, do município de Paracambi, Estado do Rio de Janeiro, no período entre 1992 e 1993. Revista da Sociedade Brasileira de Medicina Tropical, v. 38, n. 2, p. 161-166, 2005.

SANTOS, J. B. et al. Fatores sócio-econômicos e atitudes em relação à prevenção domiciliar da leishmaniose tegumentar americana, em uma área endêmica do sul da Bahia, Brasil. Cadernos de Saúde Pública, v. 16, n. 3, p. $701-708,2000$.

SCHUBACH, A. et al. Cutaneous scars in american tegumentary leishmaniasis patients: a site of Leishmania (Viannia) braziliensis persistence and viability eleven years after antimonial therapy and clinical cure. American Journal of Tropical Medicine and Hygiene, v. 58, n. 6, p. $824-827,1998$

SCHUBACH, T. M. P. et al. American cutaneous leishmaniasis in two cats from Rio de Janeiro, Brazil: first report of natural infection with Leishmania (Viannia) braziliensis. Transactions of the Royal Society of Tropical Medicine and Hygiene, v. 98, n. 2, p. 165-163, 2004.

Secretaria de Saúde do Estado do Rio de Janeiro. Notificaçóes de LTA no período de 1997-2002. Rio de Janeiro, 2003. 1 CD ROM.

SILVEIRA, T. G. V. et al. Observaçóes sobre o diagnóstico laboratorial e a epidemiologia da leishmaniose tegumentar no Estado do Paraná, sul do Brasil. Revista da Sociedade Brasileira de Medicina Tropical, v. 32, n. 4, p. 413-423, 1999.

TEODORO, U. et al. Impacto de alteraçôes ambientais na ecologia de flebotomíneos no sul do Brasil. Cadernos de Saúde Pública, v. 15, n. 4, p. 901-906, 1999.

TOLEZANO, J. E. Ecoepidemiological aspects os american cutaneous leishmaniasis in State of São Paulo, Brazil. Memórias do Instituto Oswaldo Cruz, v. 89, n. 3, p. 427-434, 1994.

UCHOA, C. M. A. et al. Aspectos sorológicos e epidemiológicos da leishmaniose tegumentar americana canina em Maricá, Rio de Janeiro, Brasil. Revista da Sociedade Brasileira de Medicina Tropical, v. 34, n. 6, p. 34, 563-568, 2001. 